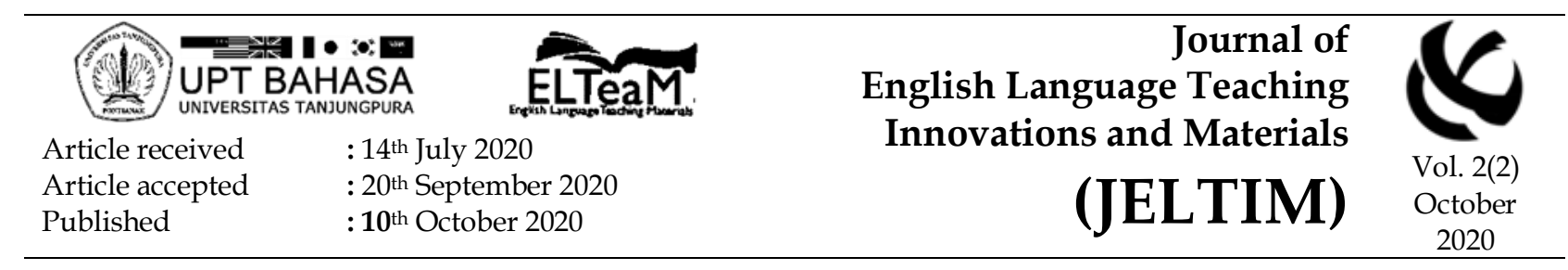

\title{
Fluency and communication strategy use in group interactions for occupational purposes
}

\author{
Megawati Soekarno1, Su-Hie Ting2 \\ 1Faculty of Psychology and Education, Universiti Malaysia Sabah, UMS Road, 88400 Kota \\ Kinabalu, Sabah, Malaysia \\ megsoekarno@gmail.com \\ ${ }^{2}$ Faculty of Language and Communication, Universiti Malaysia Sarawak, 94300 Kota \\ Samarahan, Sarawak, Malaysia \\ shting@unimas.my
}

\section{DOI: http://dx.doi.org/10.26418/jeltim.v2i2.41363}

\begin{abstract}
Communication strategy use varies with proficiency in the target language and less proficient learners rely on L1 strategies for conversational repair. In an English for Occupational Purposes (EOP) context where the technical register is unfamiliar, little is known on whether communication strategies can enable learners with limited English proficiency to overcome hesitancy in speech. The study examined learners' use of communication strategies and fluency in group interactions in an EOP context using an integrated problem-solving, interactional and discourse-based framework of communication strategies. A 13-week communication strategy training was conducted focusing on conversational repair strategies (fillers, approximation, code-switching), meaning negotiation strategies (clarification request, comprehension check, confirmation check), response strategies (rephrase, shadowing, reply) and discourse-based strategies (lexical repetition, topic fronting). The results on communication strategy use in three group interaction sessions involving three participants showed that the most frequently used communication strategies were lexical repetition and fillers. The participants' fluency, as measured in Cunits and frequency of fillers, was higher when they interacted on familiar topics. The participants learnt to use discourse-based strategies but not meaning negotiation strategies. The findings suggest that for better negotiation of meaning, the communication strategy training needs to create metacognitive awareness of the interlocutors' communicative needs.
\end{abstract}

Keywords: Communication strategies; fluency; English for Occupational Purposes; group presentation; strategic competence

Journal of English Language Teaching Innovations and Materials (JELTIM), 2(2), 63-84

Copyright (C) 2020 by JELTIM, e-ISSN 2657-1617 
How to cite this paper: Soekarno, M., \& Ting, S. H. (2020). Fluency and communication strategy use in group interactions for occupational purposes. Journal of English Language Teaching Innovations and Materials (JELTIM), 2(2), 6384. DOI: http://dx.doi.org/10.26418/jeltim.v2i2.41363

In the area of strategic competence, communication strategies have been studied from the perspectives of social interaction (Tarone, 1977), problem solving (Dörnyei, 1995; Færch \& Kasper, 1980) and, more recently, discourse (Clennell, 1995). Communication strategies are consciously used by an individual to "overcome the crisis which occurs when language structures are inadequate to convey the individual's thought" (Tarone, 1977, p. 195). Examples of communication strategies are avoidance, paraphrase, conscious transfer, appeal for assistance and mime (Tarone, 1977) as well as restructuring (Færch \& Kasper, 1980). In Færch and Kasper's (1980) terminology, avoidance constitutes a functional reduction because the speaker does not achieve the communication of the intended message. Clennell (1994) argued that communication strategies are not limited to short-term conversational repair. His contribution to the study of communication strategies is the discoursebased perspective whereby certain communication strategies are used to facilitate or enhance the message before a communication breakdown occurs. Clennell $(1994,1995)$ proposed three discourse-based strategies (tonicity, topic fronting and lexical repetition plus tone). Ting and Phan (2008) were the first to combine the problem-solving, interactional and discourse-based perspectives into an integrated framework of communication strategies, and this framework was later used by other researchers to study use of communication strategies (e.g., Illiyas, 2014).

\section{Strategic competence and communication strategy use}

Strategic competence is "activated when learners wish to convey messages which their linguistic resources do not allow them to express successfully" (Dörnyei \& Thurrell, 1991, p. 18); that is why it is useful for less proficient speakers to use communication strategies. Research has shown that less proficient speakers use communication strategies differently from proficient speakers. For example, Ting and Phan (2008) found that proficient speakers use tonicity to draw attention to key information but the less proficient speakers rely on language switch for ease of expression. The proficient speakers use language switch for a more sophisticated communicative purpose, that is, to achieve rhetorical effect by tapping into meanings associated with particular cultures. However, the two most common communication strategies used by proficient speakers in their study are restructuring and lexical repetition. Another study on a similar group of language learners revealed that lexical

Journal of English Language Teaching Innovations and Materials (JELTIM), 2(2), 63-84

Copyright ( 2020 by JELTIM, e-ISSN 2657-1617 
repetition is primarily used for topic maintenance, emphasis and establishment of rapport (Ting \& Kho, 2009). Ting and Kho (2009) found that discourse-based strategies are useful for enhancing the clarity of the message in cross-gender interactions. Female speakers frequently restructure their utterances but in cross-gender interactions, the female speakers are more likely to use topic fronting to pre-empt their interlocutors to pay attention to the topic. The male speakers frequently use approximation when they are interacting with male interlocutors but are more likely to use lexical repetition in cross-gender interactions. The learners in both studies can be considered proficient because they were teacher trainees enrolled in a degree programme preparing them to teach English as a second language (ESL) in Malaysian secondary schools. Zhu, Liao, and Cheong (2019) also found that the Hong Kong university students' proficiency influences effectiveness of strategy use. Their findings showed that the high-performing participants use a significantly higher number of active engagement, clarification, and synthesis strategies than the medium-performing participants for constructing content in the group discussion.

In comparison, the less proficient speakers in the Malaysian setting often fall back on the use of first language (L1) communication strategies when they are unable to find a word in the target language (Kuen, Rafik-Galea, \& Heng, 2017; Paramasivam, 2009). For example, it is common in Malaysia to come across speakers who begin a conversation in one language and then to switch to another before reverting to the initial language (Nadarajan, 2007). When they cannot continue, they abandon their effort but if they can use communication strategies such as restructuring and paraphrase, they can still go on in their communication. Even guessing (Dörnyei \& Scott, 1995a, 1995b), coinage, literal translations and borrowing (Færch \& Kasper, 1980) can help learners to go on in their communication. A conversational repair is particularly important when the communication involves less familiar, abstract topics and low frequency vocabulary. Less proficient speakers can talk about predictable, familiar topics related to daily activities (Swender, 1999) but often make pronunciation, grammar and vocabulary mistakes, and are hesitant in their speech. Besides Malaysian learners, other Asian learners also have poor mastery of communicative competence despite many years of learning English (Pham, 2014; Sattayatham \& Honsa, 2007, Sioco \& De Vera, 2018). By using appropriate communication strategies, less proficient speakers can appear more fluent than is otherwise permitted by their linguistic resources. Dagarin (2004) stated that the use of communication strategies "encourages students to become effective communicators in a foreign language" (p. 128).

\section{Communication strategy training}

In view of the usefulness of communication strategies, researchers investigated the feasibility of communication strategy training. The pioneering study by Dörnyei (1995) was conducted in high school EFL classes in Hungary

Journal of English Language Teaching Innovations and Materials (JELTIM), 2(2), 63-84

Copyright ( 2020 by JELTIM, e-ISSN 2657-1617 
over a period of six weeks with a focus on topic avoidance and replacement, circumlocution, and fillers. The conclusion drawn was that practical considerations and experience appear to support the usefulness of training learners to use specific communication strategies (Dörnyei, 1995). He also asserted that to improve learners' fluency, communication strategies have to be taught explicitly to the learners. Subsequently, Foster (1998) observed the language produced by intermediate English as a Foreign language (EFL) students engaged in information exchange tasks in both dyads and small groups. Foster (1998) calculated the number of interactions that were fully negotiated and omitted fillers, counting only those that elicited responses. Foster reported that a majority of students in small groups did not speak at all and preferred to abandon the message. However, Nakatani (2005) was able to produce evidence of the usefulness of communication strategy training in teaching learners to use achievement strategies and avoid reduction strategies when they encountered communication breakdowns. Similarly, Jamshidnejad (2011) also showed how the use of communication strategies gave EFL learners the opportunities to collaborate in problem solving and to practise their knowledge of the target language. Communication strategy training can significantly reduce speaking anxiety (Tsai, 2018). The training also significantly increases the number of communication strategies used by Norwegian secondary school students in Bøhn and Myklevold's (2018) study because it increases their metacognitive awareness of strategy use.

Thus far, most of these studies on communication strategy use and training were conducted on ESL and EFL learners. Guo (2011) had noted that most past studies concentrated on learners using communication strategies in the context of learning a target language. Little is known about the use of communication strategies in an EOP context where technical register makes communication even more challenging - whether it is in the form of progress reports, project discussions, emergency meetings or daily briefings. This technical language is represented by Scientific English (Carrió Pastor \& Gimeno Sanz, 2007; Ventola, 1992) which is the specific language used by experts in their communities. A lot of Malaysian learners do not realise that communicative competence in the technical language is a requirement for employment today (Pandey \& Pandey, 2014). What learners are taught does not match the demands on their communicative skills in non-educational contexts (Færch \& Kasper, 1986). As communication strategy use in an EOP context is less understood, research is needed to shed light on the possible usefulness of communication strategy training to help learners continue their communication despite inadequate linguistic resources and obstacles in the form of technical jargon. 
The case study examined the use of communication strategies and fluency in group interactions during communication strategy training in an EOP context.

\section{METHOD}

The communication strategy training involved 23 students enrolled in a Malaysian Skills Certificate (Culinary) programme in a hospitality college in Sabah, Malaysia, training them for employment in the hospitality industry as kitchen assistants, chef de partie and skilled sous chefs. This paper reports the results of a case study focussing on three students in all the group interactions during the training.

\section{Participants}

The participants were in their early twenties (P10, P16 and P17). Although they were taught English as a second language in school, they hardly spoke English in daily lives as they could use their ethnic language or Malay for daily communication. They are considered less proficient speakers of English although they had passed English at Sijil Pelajaran Malaysia (SPM or the Malaysian Certificate of Education) level (Table 1).

P10 is a Chinese female with a credit in her Sijil Pelajaran Malaysia (SPM, Malaysian Certificate of Education) English result. She was already quite proficient in both English and the Sabah Malay (Labuan) dialect. She claimed that she spoke English primarily with her family, and she was observed to be able to converse with her lecturers quite well and was outspoken in class. The other two male participants (P16 and P17) had passes in English at SPM level. P16 was a male trainee from the Brunai ethnic group with limited English proficiency and could not respond in complex interactions with the researcher and at times code switched when interacting with the college lecturers. P17, a Kadayan male, was more proficient in English and spoke English with lecturers. All three of them were proficient in Malay, which is the national language of Malaysia.

Besides the SPM results and the American Council on the Teaching of Foreign Languages (ACTFL) descriptors, the Subject Matter Expert's (SME) evaluation of the participants' language proficiency is also given in Table 1. Based on the SME's evaluation, P10 and P17 had improved in their language production and were more confident at the end of the training. The SME had 27 years of experience in Human Capital Management (HCM) and was a senior lecturer teaching subjects such as Human Resource Management, Professional Development, Communication Skills and Business Foundation in a private institution at the time of the study. She had graduated with a BA in Business

Journal of English Language Teaching Innovations and Materials (JELTIM), 2(2), 63-84

Copyright ( 2020 by JELTIM, e-ISSN 2657-1617 
Administration from University of Boston (2005) and a Master in Human Capital Management from Universiti Malaysia Sabah (2008).

Table 1. English proficiency of participants

\begin{tabular}{|c|c|c|c|}
\hline \multirow{2}{*}{ Participant } & \multicolumn{3}{|c|}{ Descriptions of Participants' English proficiency } \\
\hline & SPM & ACTFL & $\begin{array}{l}\text { SME's assessment of } \\
\text { participants' language } \\
\text { proficiency }\end{array}$ \\
\hline P10 & $\begin{array}{l}\text { Credit in } \\
\text { English } \\
\text { (Grade C) } \\
\text { Marks } 50- \\
54 \\
\text { CGPA } 2.50\end{array}$ & $\begin{array}{l}\text { Intermediate. } \\
\text { Create with language, initiate, } \\
\text { maintain, and bring to a close } \\
\text { simple conversation by asking } \\
\text { and responding to simple } \\
\text { questions. } \\
\text { Understood with some } \\
\text { repetition, by speakers } \\
\text { accustomed to non-native } \\
\text { speakers. } \\
\text { Produce paragraph text types. }\end{array}$ & $\begin{array}{l}\text { Pre-test: } \\
\text { P10 could use appropriate } \\
\text { greetings and formulaic } \\
\text { expressions. } \\
\text { Post-test: } \\
\text { P10 changed the topic by } \\
\text { abruptly asking about the } \\
\text { weather. The confidence } \\
\text { level is better than the } \\
\text { Pre-CST. }\end{array}$ \\
\hline P16 & $\begin{array}{l}\text { Pass in } \\
\text { English } \\
\text { (Grade D) } \\
\text { Marks } 45 \text { - } \\
49 \\
\text { CGPA } 2.25\end{array}$ & $\begin{array}{l}\text { Novice. } \\
\text { Communicate minimally with } \\
\text { formulaic and rote utterances, } \\
\text { lists, and phrases. } \\
\text { May be difficult to } \\
\text { understand, even for speakers } \\
\text { accustomed to non-native } \\
\text { speakers. } \\
\text { Produce individual words } \\
\text { and phrases. }\end{array}$ & Data not available. \\
\hline P17 & $\begin{array}{l}\text { Pass in } \\
\text { English } \\
\text { (Grade D) } \\
\text { Marks } 45 \text { - } \\
49 \\
\text { CGPA } 2.25\end{array}$ & $\begin{array}{l}\text { Novice/Intermediate. } \\
\text { Communicate minimally with } \\
\text { formulaic and rote utterances, } \\
\text { lists, and phrases. } \\
\text { Understood with some } \\
\text { repetition, by speakers } \\
\text { accustomed to non-native } \\
\text { speakers. } \\
\text { Produce discrete sentences. }\end{array}$ & $\begin{array}{l}\text { Pre-test: } \\
\text { P17 was able to conclude } \\
\text { the conversation very } \\
\text { well. } \\
\text { Post-test: } \\
\text { P17 could respond } \\
\text { appropriately despite the } \\
\text { frequent topic shifts by } \\
\text { his partner. English and } \\
\text { confidence improved. }\end{array}$ \\
\hline
\end{tabular}

\section{Data collection procedures}

Data were collected at five points during the 13-week communication strategy training (Table 2), and for this paper the data for the three group 
interactions (Sessions 8, 9 and 10) were analysed and reported. Group interactions were selected because in an EOP context, small group communication involves helping behaviour and information sharing which are important elements of workplace communication related to decision making and problem solving. Each session began with a 15-minute lecture on the selected communication strategy, the topic of the task, and class procedures. The trainer also encouraged the learners to explicitly use the strategy during the group interactions.

Table 2. Communication strategy training: Focus and task

\begin{tabular}{|c|c|c|}
\hline Session & Communication strategy taught & Task \\
\hline 1 & $\begin{array}{l}\text { Using fillers to keep the communication } \\
\text { channel open }\end{array}$ & $\begin{array}{l}\text { Dyadic role-play on workplace } \\
\text { topics }\end{array}$ \\
\hline 2 & $\begin{array}{l}\text { Asking for repetition to show that s/he } \\
\text { did not hear or understand what the } \\
\text { partner had said }\end{array}$ & $\begin{array}{l}\text { Dyadic role-play in giving } \\
\text { directions }\end{array}$ \\
\hline 3 & $\begin{array}{l}\text { Appealing for help by asking for the } \\
\text { correct item or structure }\end{array}$ & $\begin{array}{l}\text { Dyadic role-play on daily routine } \\
\text { topics }\end{array}$ \\
\hline 4 & $\begin{array}{l}\text { Using circumlocution for conversational } \\
\text { repair }\end{array}$ & $\begin{array}{l}\text { Individual presentation of } \\
\text { anecdotal report }\end{array}$ \\
\hline 5 & $\begin{array}{l}\text { Using approximation of alternative } \\
\text { expressions with similar semantic } \\
\text { features to the intended term }\end{array}$ & $\begin{array}{l}\text { Individual presentation of } \\
\text { incident report }\end{array}$ \\
\hline 6 & $\begin{array}{l}\text { Restructuring by reformulating the } \\
\text { syntax of the utterance }\end{array}$ & $\begin{array}{l}\text { Individual presentation of } \\
\text { analysis report (lab/field) }\end{array}$ \\
\hline 7 & $\begin{array}{l}\text { Using tonicity to mark key information } \\
\text { or to differentiate given from new } \\
\text { information }\end{array}$ & $\begin{array}{l}\text { Group discussion of project } \\
\text { proposal, followed by Q\&A }\end{array}$ \\
\hline 8 & Using topic fronting for topic emphasis & $\begin{array}{l}\text { Group discussion of progress } \\
\text { report, followed by Q\&A }\end{array}$ \\
\hline 9 & $\begin{array}{l}\text { Using lexical repetition of words or } \\
\text { phrases for facilitating information } \\
\text { transfer }\end{array}$ & $\begin{array}{l}\text { Group discussion of project } \\
\text { report, followed by Q\&A }\end{array}$ \\
\hline 10 & $\begin{array}{l}\text { Checking confirmation to affirm that the } \\
\text { speaker has understood something } \\
\text { correctly }\end{array}$ & $\begin{array}{l}\text { Forum on risk management (e.g., } \\
\text { sexual harassment, pest, } \\
\text { equipment malfunction) }\end{array}$ \\
\hline 11 & $\begin{array}{l}\text { Checking comprehension to see if the } \\
\text { listener has understood correctly }\end{array}$ & $\begin{array}{l}\text { Group role-play on crisis } \\
\text { management }\end{array}$ \\
\hline 12 & $\begin{array}{l}\text { Requesting clarification when the } \\
\text { speaker does not entirely comprehend } \\
\text { something }\end{array}$ & $\begin{array}{l}\text { Individual interaction with } \\
\text { instructor on negligence and } \\
\text { malpractice }\end{array}$ \\
\hline 13 & $\begin{array}{l}\text { Responding by rephrasing, shadowing } \\
\text { or offering the target item to a } \\
\text { negotiation signal }\end{array}$ & $\begin{array}{l}\text { Dyadic task involving small talk in } \\
\text { an authentic workplace setting }\end{array}$ \\
\hline
\end{tabular}

Journal of English Language Teaching Innovations and Materials (JELTIM), 2(2), 63-84 Copyright ( 2020 by JELTIM, e-ISSN 2657-1617 
In Session 1, the students were taught how to use time gaining strategies (e.g., hesitation devices such as fillers and other formulaic expressions). The output was a dyadic role-play on topics related to workplace communication, and this constituted the pre-test data for this study. These fillers include "um" and words, which Illiyas (2014) refer to as lexicalised fillers.

In Sessions 2 and 3, the focus was on strategies to seek the interactant's help. In Session 2, participants were taught an indirect request for help, that is, asking the interactant to repeat an utterance. This is based on Nakatani (2005), where participants were taught to ask for a repetition if they had not heard or understood what their interlocutor had said. However, the next session focussed on a direct appeal for assistance following Ting and Phan (2008), where the participants were taught to ask for the correct item or structure. At the end of Sessions 2 and 3, dyadic role-plays were conducted involving giving of directions and daily routine respectively.

The fourth to the sixth sessions were on lexical strategies, circumlocution, approximation and restructuring respectively. Table 3 provides the definition of these communication strategies. The output tasks for these three sessions were individual presentations in the form of observation reports and technical reports.

Session 7 trained participants to use tonicity (stress and pitch to mark key information or to differentiate given from new information), a discoursebased communication strategy adopted from Clennell (1994) but not included in Nakatani's (2005) communication strategy training. In groups, participants discussed to propose a project. For example, camping (retreat), telematch, English Day and Culinary Family Day. This session was not recorded due to the participants' unfamiliarity with the topic and to enable them to feel less inhibited as this was the first group discussion during the training.

Session 8 trained participants to use another of Clennell's (1994) discourse-based communication strategy: topic fronting (using subject plus predicate syntactic structure to parcel up information to emphasise the topic). Participants discussed the details of the progress report, including budget and other event specifics. Both the discussion and Question-and-Answer session were recorded for analysis.

In Session 9, the participants were taught lexical repetition, the third and last of Clennell's (1994) discourse-based strategies. Table 3 shows the five varied functions of lexical repetition as identified from Ting and Phan's (2008) study. Session 9 was concluded with a group presentation of the project report using powerpoint slides, followed by a Q\&A session. 
Table 3. Analysis framework for the identification of communication strategies

\begin{tabular}{|c|c|c|}
\hline Strategy & Description & Example \\
\hline 1. Fillers (fillers) & $\begin{array}{l}\text { The speaker uses time gaining strategies - } \\
\text { fillers etc. to think and to keep the } \\
\text { communication channel open. }\end{array}$ & $\begin{array}{l}\text { Actually what I'm } \\
\text { trying to say is }\end{array}$ \\
\hline $\begin{array}{ll}\text { 2. } & \text { Clarification } \\
\text { request (clreq) }\end{array}$ & $\begin{array}{l}\text { The speaker asks for an explanation when } \\
\text { the speaker does not entirely comprehend } \\
\text { something which sometimes include } \\
\text { repeated words or phrases. }\end{array}$ & $\begin{array}{l}\text { What do you mean, } \\
\text { madam? }\end{array}$ \\
\hline $\begin{array}{l}\text { 3. Comprehension } \\
\text { check (compre) }\end{array}$ & $\begin{array}{l}\text { The speaker queries to see if the listener has } \\
\text { understood correctly which sometimes } \\
\text { include repeated words or phrases. }\end{array}$ & $\begin{array}{l}\text { Okay, so two } \\
\text { activities huh? }\end{array}$ \\
\hline $\begin{array}{l}\text { 4. Confirmation } \\
\text { check (check) }\end{array}$ & $\begin{array}{l}\text { The speaker queries to affirm he has } \\
\text { understood something correctly which } \\
\text { sometimes include repeated words or } \\
\text { phrases. }\end{array}$ & Is that correct? \\
\hline $\begin{array}{ll}\text { 5. } & \text { Response } \\
\text { rephrase } \\
\text { (Rephr) }\end{array}$ & $\begin{array}{l}\text { The speaker restructures the syntax of an } \\
\text { utterance in response to their conversation } \\
\text { partners' signals for negotiation. }\end{array}$ & $\begin{array}{l}\text { So is it really, do you } \\
\text { need to utilize the } \\
\text { one hour for } \\
\text { "Finding the } \\
\text { difference"? }\end{array}$ \\
\hline $\begin{array}{l}\text { 6. Response } \\
\text { shadowing } \\
\text { (shadow) }\end{array}$ & $\begin{array}{l}\text { The speaker uses the exact, partial or } \\
\text { expanded repetitions of the interlocutor's } \\
\text { preceding utterance in order to show the } \\
\text { listener's understanding of important issues. }\end{array}$ & Yeah, one five. \\
\hline $\begin{array}{ll}\text { 7. } & \text { Response } \\
\text { utterance } \\
\text { (Reply) }\end{array}$ & $\begin{array}{l}\text { The speaker offers the target item to the } \\
\text { interlocutor. }\end{array}$ & $\begin{array}{l}\text { No, we just } \\
\text { approximate about } \\
\text { the time. }\end{array}$ \\
\hline $\begin{array}{l}\text { 8. } \begin{array}{l}\text { Lexical } \\
\text { repetition (rptn) }\end{array}\end{array}$ & $\begin{array}{l}\text { The speaker repeats words or phrases with } \\
\text { a system of tones for discourse and topic } \\
\text { maintenance, topic salience marker, appeal } \\
\text { for assistance, request for clarification and } \\
\text { to indicate comprehension. }\end{array}$ & $\begin{array}{l}\text { But maybe if } \\
\text { anything change, } \\
\text { anything change, in } \\
\text { the here we will } \\
\text { inform. }\end{array}$ \\
\hline $\begin{array}{l}\text { 9. Topic fronting } \\
\text { (fronting) }\end{array}$ & $\begin{array}{l}\text { The speaker makes use of subject plus } \\
\text { predicate syntactic structure to parcel up } \\
\text { information to emphasise the topic. }\end{array}$ & $\begin{array}{l}\text { Then our venue, we } \\
\text { will do it at Ascot } \\
\text { Academy [umm] if } \\
\text { we can use the venue } \\
\text { here. }\end{array}$ \\
\hline $\begin{array}{l}\text { 10. Approximation } \\
\text { (approx) }\end{array}$ & $\begin{array}{l}\text { The speaker uses an alternative expression } \\
\text { that had semantic features similar to those } \\
\text { of the intended term. }\end{array}$ & $\begin{array}{l}\text { So you wear the } \\
\text { suitable [uhh] } \\
\text { footwear, it will } \\
\text { [umm] [...] }\end{array}$ \\
\hline $\begin{array}{l}\text { 11. Code switching } \\
\text { (cs) }\end{array}$ & $\begin{array}{l}\text { The speaker mixes words from another } \\
\text { language to communicate well. }\end{array}$ & $\begin{array}{l}\text { Sorry, ada "A" } \\
\text { tersalah. }\end{array}$ \\
\hline
\end{tabular}

Note: In Column 1, the words in brackets show the coding of communication strategies

Journal of English Language Teaching Innovations and Materials (JELTIM), 2(2), 63-84

Copyright ( 2020 by JELTIM, e-ISSN 2657-1617 
From Session 10 to Session 12, three meaning negotiation strategies in Tarone's (1977) taxonomy were taught. Session 10 was on confirmation checks where the speaker queries to affirm he has understood something correctly (Nakatani, 2005) which may involve repeating words or phrases with a questioning tone (Ting \& Phan, 2008). By this time, the topic had become more technical - risk management covering potential hazards identified in the Ascot Competency Profile. The participants conducted a forum on the identification of the severity of internal risks and possible solutions, and the data were analysed for this paper. In Sessions 11 and 12, participants were trained to use comprehension checks and clarification request respectively.

The final session in the communication strategy training was on two types of response utterances. For response negotiation, the participants were taught how to rephrase an utterance in response to their conversation partners' signals for negotiation. For reply statement, the participants were taught how to offer the target item to their interlocutor. The output was a dyadic task involving small talk in a workplace context, and participants had to use technical terms.

The recordings were done by the participants using their mobile phones so that their interactions would be more natural. However, the first researcher made it clear that they could not rehearse their speech before the recording. The three sessions (S8, S9 and S10) were selected to examine communication strategy use and fluency of participants as they moved from making a progress report (S8) to a project report (S9) for organising an event. S7 was a project proposal but the group interaction was not recorded. In S10, participants discussed how to manage a crisis (e.g., equipment malfunction in the kitchen) and this is a more technical subject matter than organising an event. This allows an examination of how their communication strategy use and fluency might be affected.

\section{Data analysis procedures}

Altogether 12 sessions were recorded, and transcribed verbatim, and fillers (e.g., umm) and changes in pitch and stress were also indicated on the transcripts. Transcriptions were done by the researcher and six participants to ensure accuracy.

Subsequently, the transcripts were coded for communication strategies. Table 3 shows the analysis framework formulated with reference to researchers in the field (Clennell, 1995; Nakatani, 2005, 2010; Soekarno \& Ting, 2016; Ting \& Phan, 2008). The coding was checked repeatedly to ensure accuracy. The first researcher counted the total number of times each strategy was used. As the word length of the transcripts for the three sessions differed, the total number of communication strategies was normalised for comparison across training session (McEnery \& Hardie, 2012). The Corpus of Contemporary English, for

Journal of English Language Teaching Innovations and Materials (JELTIM), 2(2), 63-84

Copyright ( 2020 by JELTIM, e-ISSN 2657-1617 
example, uses per million calculations in the chart display for comparisons across text-types. The convention is to calculate per 1000 words (ptw) as follows:

$\underline{\text { Total Communication Strategies }}$ Word count of trancript

Next, the transcripts were analysed for fluency. C-unit includes only meaningful words, that is, an utterance such as a word, phrase or sentence that gives referential or pragmatic meaning to an interaction even if they are incomplete (Brock, 1986; Foster, 1998; Huang, 2009; Nakatani, 2005) but it is a clearly recognisable unit of communication. Words, or parts of words, or fragments (i.e., to reconsi-, filled pauses umm/uhh) which are not meaningful are not considered part of the C-unit and are called mazes. The total number of $\mathrm{C}$-units per transcript was counted. Then the number of $\mathrm{C}$-unit per thousand words for a particular participant was calculated to facilitate comparison with the number of communication strategies ptw (Table 6) as follows:

$$
\frac{\text { No. of C-units }}{\text { Word count of transcript }} \times 1000=\text { No. of C-units ptw }
$$

\section{FINDINGS}

Table 4 shows the data set for the study. P10 was in her group for the three sessions. P16 and P17 were in the same group in Sessions 8 and 9 but in different groups in Session 10.

Table 4. Data set for communication strategies and fluency for the three participants

\begin{tabular}{cccccc}
\hline Session & $\begin{array}{c}\text { Duration of } \\
\text { recording } \\
\text { (minutes) }\end{array}$ & $\begin{array}{c}\text { Total word } \\
\text { count for } \\
\text { whole } \\
\text { group } \\
\text { (words) }\end{array}$ & $\begin{array}{c}\text { Total word } \\
\text { count for 3 } \\
\text { participants } \\
\text { (words) }\end{array}$ & $\begin{array}{c}\text { Total } \\
\text { communication } \\
\text { strategies used by } \\
\text { 3 participants }\end{array}$ & $\begin{array}{c}\text { Total C-units } \\
\text { for 3 } \\
\text { participants }\end{array}$ \\
\hline 8 & 7.36 & 765 & 399 & 17 & 44 \\
9 & 38.49 & 3,562 & 395 & 12 & 71 \\
10 & 22.60 & 1,949 & 443 & 16 & 43 \\
\hline & 68.45 & 6,276 & 1,237 & 47 & 158 \\
\hline
\end{tabular}

Journal of English Language Teaching Innovations and Materials (JELTIM), 2(2), 63-84

Copyright ( 2020 by JELTIM, e-ISSN 2657-1617 


\section{Use of communication strategies}

Table 5 shows that it is easier for the participants to learn topic fronting and lexical repetition than confirmation check. In Session 8, topic fronting was taught and the results show that it is the most frequently used communication strategy in this session (6 times or 4.85 strategies ptw) - and mainly by P10. Excerpt 1 (lines 7-8) shows how P10 named the subject (e.g., "Then our venue") before continuing with the predicate syntactic structure (e.g., "we will do it as Ascot Academy") to alert her audience to the subject matter. During the introduction of the project, P10 was using mainly topic fronting and fillers but when she answered questions, she used topic fronting and lexical repetition. P17 was also able to use topic fronting and fillers but P16 had to be prompted to talk and often gave one-word answers (e.g., "yeah", activity). Topic fronting is a feature of Malaysian English (Benson, 1990), which could explain why it was easier for the participants to demonstrate use of this strategy in the training session itself.

Table 5. Frequency of strategies used by individuals in group presentations

\begin{tabular}{|c|c|c|c|c|c|c|c|c|c|c|c|c|c|c|}
\hline & $\begin{array}{l}\text { S8, } \\
\text { P10 }\end{array}$ & $\begin{array}{l}\text { S8, } \\
\text { P16 }\end{array}$ & $\begin{array}{l}\text { S8, } \\
\text { P17 }\end{array}$ & $\begin{array}{c}\text { S8 } \\
\text { Total }\end{array}$ & $\begin{array}{l}\text { S9, } \\
\text { P10 }\end{array}$ & $\begin{array}{l}\text { S9, } \\
\text { P16 }\end{array}$ & $\begin{array}{l}\text { S9, } \\
\text { P17 }\end{array}$ & $\begin{array}{c}\text { S9 } \\
\text { Total }\end{array}$ & $\begin{array}{l}\text { S10, } \\
\text { P10 }\end{array}$ & $\begin{array}{l}\text { S10, } \\
\text { P16 }\end{array}$ & $\begin{array}{l}\text { S10, } \\
\text { P17 }\end{array}$ & $\begin{array}{c}\text { S10 } \\
\text { Total }\end{array}$ & $\begin{array}{c}\text { Total } \\
\text { CS }\end{array}$ & $\begin{array}{l}\text { TCS } \\
\text { ptw }\end{array}$ \\
\hline $\begin{array}{l}\text { Lexical } \\
\text { Repetition }\end{array}$ & 1 & & 1 & $\begin{array}{c}2 \\
(1.62 \\
\text { ptw) }\end{array}$ & & & 3 & $\begin{array}{c}3 \\
(2.43 \\
\text { ptw) }\end{array}$ & & 2 & 5 & $\begin{array}{c}7 \\
(5.66 \\
\text { ptw) }\end{array}$ & 12 & 9.70 \\
\hline Filler & 2 & & 1 & $\begin{array}{c}3 \\
(2.43 \\
\text { ptw) }\end{array}$ & & & 1 & $\begin{array}{c}1 \\
(0.81 \\
\text { ptw) }\end{array}$ & & 1 & 5 & $\begin{array}{c}6 \\
(4.85 \\
\text { ptw) }\end{array}$ & 10 & 8.08 \\
\hline $\begin{array}{l}\text { Topic } \\
\text { fronting }\end{array}$ & 5 & & 1 & $\begin{array}{c}6 \\
(4.85 \\
\text { ptw) }\end{array}$ & & & 1 & $\begin{array}{c}1 \\
(0.81 \\
\text { ptw })\end{array}$ & & & & 0 & 7 & 5.66 \\
\hline Reply & 1 & 1 & 2 & $\begin{array}{c}4 \\
(3.23 \\
\text { ptw) }\end{array}$ & & & 1 & $\begin{array}{c}1 \\
(0.81 \\
\text { ptw) }\end{array}$ & & & & 0 & 5 & 4.04 \\
\hline Shadowing & & & 1 & $\begin{array}{c}1 \\
(0.81 \\
\text { ptw })\end{array}$ & & & 2 & $\begin{array}{c}2 \\
(1.62 \\
\text { ptw) }\end{array}$ & 1 & & & $\begin{array}{c}1 \\
(0.81 \\
\text { ptw) }\end{array}$ & 4 & 3.23 \\
\hline Approximation & & & & 0 & & & 1 & $\begin{array}{c}1 \\
(0.81 \\
\text { ptw) }\end{array}$ & & & 1 & $\begin{array}{c}1 \\
(0.81 \\
\text { ptw) }\end{array}$ & 2 & 1.62 \\
\hline $\begin{array}{l}\text { Clarification } \\
\text { request }\end{array}$ & & & & 0 & 1 & & & $\begin{array}{c}1 \\
(0.81 \\
\text { ptw) }\end{array}$ & & 1 & & $\begin{array}{c}1 \\
(0.81 \\
\text { ptw) }\end{array}$ & 2 & 1.62 \\
\hline $\begin{array}{l}\text { Code } \\
\text { switch }\end{array}$ & & & & 0 & 1 & & & $\begin{array}{c}1 \\
(0.81 \\
\text { ptw) }\end{array}$ & & & & 0 & 1 & 0.81 \\
\hline $\begin{array}{l}\text { Comprehension } \\
\text { check }\end{array}$ & & & 1 & $\begin{array}{c}1 \\
(0.81 \\
\text { ptw) }\end{array}$ & & & & 0 & & & & 0 & 1 & 0.81 \\
\hline $\begin{array}{l}\text { Rephrasing } \\
\text { response }\end{array}$ & & & & 0 & & & 1 & $\begin{array}{c}1 \\
(0.81 \\
\text { ptw })\end{array}$ & & & & 0 & 1 & 0.81 \\
\hline $\begin{array}{l}\text { Confirmation } \\
\text { check }\end{array}$ & & & & 0 & & & & 0 & & & & 0 & & 0 \\
\hline $\begin{array}{l}\text { Total CS per } \\
\text { individual }\end{array}$ & 9 & 1 & 7 & 17 & 2 & 0 & 10 & 12 & 1 & 4 & 11 & 16 & 45 & 36.38 \\
\hline
\end{tabular}




\section{Excerpt 1}

1 P10: Madam and fellow friends, today we going to talk about our

2 progress and our proposal. We [actually] filler had our first proposal

3 but we had a lot of issues, [uhh] so we come out with a new idea

4 to talk, to start our new proposal project. [So, this project] ${ }^{\text {filler }}$ [uhh]

5 [this project [uhh] we started,] fronting we had an idea about [uhh]

6 to start an English day event. Our objective on this English day is

7 to [uhh] let [uhh] student improve their language of English and

8 to improve the camaraderie between student. [Then our

9 venue, ] fronting we will do it at Ascot Academy [umm] if we can use

10 the venue here. [Participants] fronting I think we [umm] around 40

11 people like that and our budget is only around [uhh] RM200 [uhh]

12 for the event specific.

13 Trainer: Okay, [so you are going to have this for all the Ascot's

14 student?] compre

In Session 9, the training focussed on lexical repetition which was used three times and all by P17; the other communication strategies were used only one to two times. Excerpt 2 illustrates the use of lexical repetition as fillers and to mark topic salience. The form of the lexical repetition advanced from a single noun form to a verb phrase and a dependent clause as the communication strategy training progressed.

\section{Excerpt 2}

1 P17: tapi tu [eh] but that is the draft, [draft, draft, draft, draft $]^{\text {rptn }}$ 2 estimate, okay and then the [...]

Session 8 (lexical repetition functions as a filler)

3 P17: [umm] Yeah [uhh] the things is it will be, // it is better than 4 nothing [uhh] // [what am I trying to say is] filler [umm] if we 5 wear the footwear, // the accident still happen but the 6 percentage of the incident will be reduce // [if we wear the 7 footwear.] $]^{\mathrm{rptn}} / /$

Session 10 (lexical repetition marks topic salience)

Session 9 shows the trainer frequently shadowing students' responses and repeating phrases to model the use of lexical repetition. Interestingly, there seems to be a delay in the effects of the training because the frequency of lexical

Journal of English Language Teaching Innovations and Materials (JELTIM), 2(2), 63-84

Copyright ( 2020 by JELTIM, e-ISSN 2657-1617 
repetition increased in Session 10 to seven times (or 5.66 times ptw). In the initial part of the group interaction, P17 affirmed using fillers (e.g., umm, huh) and one-word replies but later, he began to use lexical repetitions. Even P16 who previously did not use lexical repetition started to repeat words and phrases in Session 10 but he was generally quiet throughout the training. As a whole, lexical repetition is the most frequently used communication strategy during the training (9.70 times ptw, Table 5).

Finally, in session 10 the participants were taught to use confirmation check but none of them queried their audience to check if they had understood the message. They also seldom used clarification request (2 times or 1.62 times $\mathrm{ptw})$; and comprehension check (1 time or 0.81 times ptw). Instead it was the trainer who frequently used meaning negotiation strategies (Excerpt 3, lines 610). Despite modelling by the trainer, the participants did not have the metacognitive awareness to look out for potential mismatches and unshared meanings. Although negotiation of meaning is seen as conducive to second language development (Nakatani, 2005, 2010; Rabab'ah, 2016; Rouhshad, Wigglesworth, \& Starch, 2016, Suraprajit, 2017), the results suggest that the learners are unable to use meaning negotiation strategies because they do not have the metacognitive awareness to monitor the communicative needs of interlocutors. Al-Gharaibeh and Al-Jamal (2016) found that Grade 10 teachers frequently use comprehension check when teaching English but at the students' level, this meaning negotiation strategy is hardly used (Soekarno \& Ting, 2016; Ting \& Kho, 2009; Ting \& Phan, 2008). It is important to allocate more time in the communication strategy training to develop their metacognitive awareness of strategy use (see also Bøhn \& Myklevold, 2018).

\section{Excerpt 3}

1 Trainer: Alright, next time you come up with this, what you need is to give 2 us some example.

$3 \quad$ Alright, perhaps two pictures.

4 [This is the first activity, right?] confm

5 [Do you need one hour to do that activity?] clreq

6 P10: [What do you mean, Madam?] clreq

7 Trainer: Because it's starting at 10 am and the next activity is going to start 8 at $11 \mathrm{am}$.

9 So is it really, [do you need to utilise the one hour for "Finding the 10 difference"? ?rephr

11 P10: Yes, because the first stage and the second stage.

12 And we need time to //

Besides the strategies taught during the training, the participants' use of 
fillers needs to be given attention because the frequency of use is the second highest (8.08 times per ptw, Table 5). For example, "We [actually] filler had our first proposal" and "[So, this project] filler [uhh] [this project [uhh] we started,]fronting. The use of fillers is normal because 20 percent of all words uttered in daily conversation are formulaic expressions which usually act as fillers (Sorhus, 1977 as cited in Norton, 2001). In the case of learners with limited English proficiency, fillers are useful to buy time to think and reduce the appearance of hesitancy in speech, enabling them to appear more fluent than they otherwise are.

\section{Fluency}

In this study, fluency is measured using C-units and frequency of fillers which is an indicator of hesitancy in speech. A larger number of C-units indicates more dense communication comprising more meaningful units whereas less $\mathrm{C}$ units indicates more hesitancy in speech. Based on the average C-units for the sessions (Table 6), the participants were the most fluent in Session 9 (project report, 1,860 C-units ptw) and the least fluent in Session 10 (forum, 1,077 Cunits ptw).

Table 6. Fluency of participants in group interactions, as measured in C-units ptw

\begin{tabular}{|c|c|c|c|c|c|c|}
\hline Session & Participant & $\begin{array}{l}\text { Word count } \\
\text { for group } \\
\text { interaction }\end{array}$ & $\begin{array}{l}\text { Word count } \\
\text { for each of } \\
\text { the } 3 \\
\text { participants }\end{array}$ & $\begin{array}{l}\text { Total } \\
\text { C-units for } \\
\text { each } \\
\text { participant }\end{array}$ & $\begin{array}{l}\text { C-units } \\
\text { per } \\
\text { thousand } \\
\text { words }\end{array}$ & $\begin{array}{l}\text { Average } \\
\text { C-units } \\
\text { ptw for } \\
\text { sessions }\end{array}$ \\
\hline \multirow{3}{*}{8} & P10 & 207 & 179 words & 21 & 1173.18 & \multirow{3}{*}{1332.05} \\
\hline & P16 & 339 & 11 words & 2 & 1818.18 & \\
\hline & P17 & & 209 words & 21 & 1004.78 & \\
\hline \multirow{3}{*}{9} & P10 & 1219 & 101 words & 32 & 3168.32 & \multirow{3}{*}{1860.38} \\
\hline & P16 & 981 & 28 words & 3 & 1071.43 & \\
\hline & P17 & & 266 words & 36 & 1353.38 & \\
\hline \multirow{3}{*}{10} & P10 & 558 & 112 words & 12 & 1071.43 & \multirow{3}{*}{1077.83} \\
\hline & P16 & 508 & 24 words & 3 & 1250.00 & \\
\hline & P17 & 556 & 307 words & 28 & 912.05 & \\
\hline
\end{tabular}

Notes:

1. The word count for the whole group interaction is given to give an indication of how much the three participants had talked during the group interaction.

2. P16 and P17 were in the same group in Sessions 8 and 9 but in different groups in Session 10.

In Session 9, they were already familiar with the event organising details after discussing it in the previous two sessions (proposal and progress report),

Journal of English Language Teaching Innovations and Materials (JELTIM), 2(2), 63-84

Copyright ( 2020 by JELTIM, e-ISSN 2657-1617 
compared to risk management which is a technical topic, indicated by the vast number of technical words in Table 7. From Session 8 to Session 9, there was an increase in range of technical words (e.g., project description, capital) but these are easy in comparison to words like "appropriate footwear" and "extension". If learners cannot use technical words related to the floor surface (e.g., oily, slippery, maximum natural reflection), they would be impeded in their communication.

Lennon (1990) classified fluency measures under temporal measures which includes hesitation markers where higher frequency indicates lower fluency. The results on fillers confirm that the most hesitant speech was produced in Session 10 where the C-unit was the lowest and the filler frequency was the highest (4.85 fillers ptw) among the three sessions.

Table 7. Technical words used by participants during the three sessions of training

\begin{tabular}{|c|c|c|c|}
\hline & Session 8 & Session 9 & Session 10 \\
\hline \multirow[t]{6}{*}{ P10 } & Camaraderie & Crossword & Equipment malfunction \\
\hline & Venue & Guessing the picture & Personal hygiene \\
\hline & Event specific & Capital & Priority \\
\hline & & & Severe damage \\
\hline & & & Categorise \\
\hline & & & Control \\
\hline \multirow[t]{2}{*}{ P16 } & - & Bonding time & Main cause \\
\hline & & & Sexual abuse \\
\hline \multirow[t]{18}{*}{ P17 } & Venue & Project description & Priority \\
\hline & Fund & Project cost & Slippery floor \\
\hline & Transportation & Contingency bus & Floor surfaces \\
\hline & Fee & Safe t-shirt & Oily surfaces \\
\hline & & Donations & Maintain a safe surface \\
\hline & & Charge them & Maximum natural reflection \\
\hline & & Transportation & Wound \\
\hline & & Expenses & Appropriate footwear \\
\hline & & & Reduce the risk \\
\hline & & & Regular cleaning \\
\hline & & & Clean agent \\
\hline & & & Polishes \\
\hline & & & Extension \\
\hline & & & Work way \\
\hline & & & Bacteria \\
\hline & & & Incident \\
\hline & & & Accident \\
\hline & & & Percentage incident \\
\hline
\end{tabular}

Journal of English Language Teaching Innovations and Materials (JELTIM), 2(2), 63-84

Copyright ( 2020 by JELTIM, e-ISSN 2657-1617 


\section{DISCUSSION}

The study shows that the communication strategy training is more successful in teaching EOP learners to use discourse-based strategies such as topic fronting and lexical repetition rather than meaning negotiation strategies such as confirmation check. The most frequently used communication strategies in this EOP context are lexical repetition and fillers. The participants' fluency, as measured in C-units and frequency of fillers, is higher during interactions on familiar topics, and lower in discussions on technical subject matters like risk management. High proficiency learners are better at using lexicalised fillers, which includes repetition and fillers, while low proficiency learners pause frequently in their spoken discourse (Illiyas, 2014).

Contrary to other studies (Soekarno \& Ting, 2016) which found that less proficient learners rely on L1 communication strategies, the present study showed that they do not. The only transfer identified from the group interaction transcripts is one instance of code switching ("Sorry ada "A" tersalah" translated as "Sorry, there's a mistake for $\mathrm{A}^{\text {") }}$ ) when a participant pointed out an error in the powerpoint slides. The EOP context for the present study is somewhat unique in that they were trained by an expatriate chef who used English, thereby compelling the participants to communicate in English and to familiarise themselves with technical terms in English. Hence, their code switches and literal translations were minimal. In the hospitality industry, service providers in the front office and housekeeping usually have technical terms interspersed with their greetings and basic interactions. It is more important for them to master the use of technical words in English than assistant chefs, maids, pool attendants, and life guards who are not in direct contact with clients, and are not expected to demonstrate proficiency in English. In this respect, communication strategy training is more essential for frontline hospitality staff.

The findings suggest that the communication strategy training needs to focus on developing metacognitive awareness of the interlocutors' communicative needs. This is an aspect which has not emerged from other studies on communication strategy training. Soekarno and Ting (2016), for example, advocated training learners with limited English proficiency on "collaborative discourse skills" (Clennell, 1995, p. 16). Ting and Phan (2008) stated that less proficient learners should be trained to use discourse strategies for meaning enhancement, as these are usually used by proficient speakers. Indeed the present study shows that learners with limited English proficiency can be trained to use discourse-based strategies as these do not require additional linguistic resources. However, the present study shows that it is not easy for learners to use meaning negotiation strategies as they may lack the metacognitive awareness to monitor communicative needs of interlocutors.

Journal of English Language Teaching Innovations and Materials (JELTIM), 2(2), 63-84

Copyright ( 2020 by JELTIM, e-ISSN 2657-1617 
Lam and Wong (2000) concur in that the Hong Kong ESL learners in their study still could not seek and provide clarification during the group discussions at the end of the communication strategy training because of their limited vocabulary. Bøhn and Myklevold (2018) investigated whether Norwegian EFL learners were using metacognitive strategies such as pre-assessment, preplanning, online planning/monitoring and post-evaluation but did not examine whether training in metacognitive awareness can lead to better use of meaning negotiation strategies. Hence, an area to explore further is the relationship between metacognitive awareness and use of meaning negotiation strategies during the process of communication strategy training.

\section{FUNDING}

This work was supported by the Universiti Malaysia Sarawak, Faculty of Language and Communication for the research on "Communication strategy use, contextual factors and language proficiency of ESL speakers in Malaysian tertiary settings", $\mathrm{NF}(\mathrm{C} 02) / 04 / 2007(04)$.

\section{REFERENCES}

Al-Gharaibeh, S. F., \& Al-Jamal, D. A. (2016). Communication strategies for teachers and their students in an EFL setting. International Journal of Bilingual \& Multilingual Teachers of English, 4(1), 33-44. DOI:10.12785/IJBMTE/040105

Benson, P. (1990). A language in decline? English Today, 6(1), 19-23.

Bøhn, H., \& Myklevold, G. A. (2018). Exploring communication strategy use and metacognitive awareness in the EFL classroom. In A. Haukås, C. Bjørke, \& M. Dypedahl (Eds.), Metacognition in language learning and teaching (pp. 179-203). New York: Routledge.

Brock, C. (1986). The effect of referential questions on ESL classroom discourse. TESOL Quarterly, 20, 47-59. https://doi.org/10.2307/3586388

Carrió Pastor, M., \& Gimeno Sanz, A. (2007). Content and language integrated learning in a technical higher education environment. In D. Marsh, \& D. Wolff (Eds.), Diverse contexts - converging goals: CLIL in Europe (pp. 103111). Frankfurt am Main: Peter Lang GmbH.

Clennell, C. (1994). Investigating the use of communication strategies by adult second language learners: A case for trusting your own judgment in classroom research. TESOL Journal, 3, 32-35.

Journal of English Language Teaching Innovations and Materials (JELTIM), 2(2), 63-84

Copyright ( 2020 by JELTIM, e-ISSN 2657-1617 
Clennell, C. (1995). Communication strategies of adult ESL learners: A discourse perspective. Prospect, 10(3), 4-20. Corpus ID: 140452063

Dagarin, M. (2004). Classroom interaction and communication strategies in learning English as a foreign language. English Language and Literature Teaching, 1(1-2), 127-139. https://doi.org/10.4312/elope.1.1-2.127-139

Dörnyei, Z. (1995). On the teachability of communication strategies. TESOL Quarterly, 29, 55-85. DOI: 10.2307/3587805

Dörnyei, Z., \& Scott, M. L. (1995a). Communication strategies: what are they and what are they not? In Z. Dörnyei, \& M. L. Scott (Eds.), Communication strategies in a second language: Definitions and taxonomies. Language Learning, 47, 173-210.

Dörnyei, Z., \& Scott, M. L. (1995b). Communication Strategies: An empirical analysis with retrospection. In Z. Dörnyei, \& M. L. Scott (Eds.), Communication strategies in a second language: Definitions and taxonomies. Language Learning, 47, 173-210.

Dörnyei, Z., \& Thurrell, S. (1991). Strategic competence and how to teach it. ELT Journal, 45(1), 16-23. http:/ /dx.doi.org/10.1093/elt/45.1.16

Færch, C., \& Kasper, G. (1980). Processes and strategies in foreign language learning and communication. Interlanguage Studies Bulletin - Utrecht, 5, 47-118. https://www.jstor.org/stable/43135245

Faerch, C., \& Kasper, G. (1986). Strategic competence in foreign language teaching. In G. Kasper (Ed.), Learning, teaching and communication in the foreign language classroom (pp. 179-193). Denmark: Aarhus Universitetsforlag.

Foster, P. (1998). A classroom perspective on the negotiation of meaning. Applied Linguistics, 19(1) 1-23. https:/ / doi.org/10.1093/applin/19.1.1

Guo, J. (2011). Empirical studies on L2 communication strategies over four decades: Looking back and ahead. Chinese Journal of Applied Linguistics, 34(4), 89-106. https:/ / doi.org/10.1515/cjal.2011.036

Huang, S. C. (2009). The efficacy of setting process goals in orienting EFL learners to attend to the formal aspects of oral production. The Asian EFL Journal Quarterly, 11(1), 74-86. Corpus ID: 147455926

Jamshidnejad, A. (2011). Developing accuracy by using oral communication strategies in EFL interactions. Journal of Language Teaching and Research, 2(3), 530-536. DOI:10.4304/jltr.2.3.530-536

Kuen, G. L., Rafik-Galea, S., \& Chan, S. H. (2017). Effect of oral communication strategies training on the development of Malaysian English as a second language learners' strategic competence. International Journal of Education

Journal of English Language Teaching Innovations and Materials (JELTIM), 2(2), 63-84

Copyright ( 2020 by JELTIM, e-ISSN 2657-1617 
and Literacy Studies, 5(4), 57-77.

Lam, W., \& Wong, J. (2000). The effects of strategy training on developing discussion skills in an ESL classroom. ELT Journal, 54(3), 245-255. https://doi.org/10.1093/elt/54.3.245

Lennon, P. (1990). Investigating fluency in EFL: A quantitative approach. Language Learning, 40, 387-417. https://doi.org/10.1111/j.14671770.1990.tb00669.x

McEnery, T., \& Hardie, A. (2012). Corpus linguistics: Method, theory and practice. UK: Cambridge University Press.

Illiyas, S. M. M. (2014). The use of fillers and hesitation devices as communication strategies among Malaysian language learners. Infrastructure University Kuala Lumpur Research Journal, 2(1), 162-175.

Nadarajan, S. (2007). The use of repetitive structures among Malaysians. The International Journal of Language Society and Culture, 22, 29-38.

Nakatani, Y. (2005). The effects of awareness-raising training on oral communication strategy use. The Modern Language Journal, 89(1), 76-91. https://www.jstor.org/stable/3588552

Nakatani, Y. (2010). Identifying strategies that facilitate EFL learners' oral communication: a classroom studying using multiple data collection procedures. The Modern Language Journal, 94(1), 116-136. https:/ / doi.org/10.1111/j.1540-4781.2009.00987.x

Norton, J. (2001). Formulaic expressions in English and Japanese: Implications for teaching and learning. Retrieved from http://cs3.brookes.ac.uk/schools/education/eal/jl-archive/jlbestof/24.pdf.

Pandey, M., \& Pandey, P. (2014). Better English for better employment opportunities. International Journal of Multidisciplinary Approach and Studies, 1(4), 93-100.

Paramasivam, S. (2009). Language transfer as a communication strategy and a language learning strategy in a Malaysian ESL classroom. The Asian EFL Journal Quarterly, 11(1), 192-229.

Pham, T. T. X. (2014). What are challenges that Vietnamese students encounter when representing themselves through speaking English? TESOL International Journal, 9(1), 125-147.

Rabab'ah, G. (2016). The effect of communication strategy training on the development of EFL learners' strategic competence and oral communicative ability. Journal of Psycholinguistic Research, 45(3), 625-651. DOI: $10.1007 /$ s10936-015-9365-3 
Rouhshad, A., Wigglesworth, G., \& Storch, N. (2016). The nature of negotiations in face-to-face versus computer-mediated communication in pair interactions. Language Teaching Research, 20(4), 514-534. https://doi.org/10.1177/1362168815584455

Sattayatnam, A., \& Honsa, S. (2007). Medical students' most frequent errors at Mahidol University, Thailand. Asian EFL Journal, 9(1), 170-195.

Sioco, E. C., \& De Vera, P. V. (2018). Grammatical competence of junior high school students. TESOL International Journal, 13(2), 82-93.

Soekarno, M., \& Ting, S. H. (2016). Communication strategy use by Healthcare trainees in monologues and dialogues during strategy training. Journal of Applied Language $\quad$ Studies, $\quad 10(1), \quad 5-26$. http:/ / dx.doi.org/10.17011/apples/urn.201603071783

Sorhus, H. (1977). To hear ourselves: Implications for teaching English as a second language. English Language Teaching Journal, 31(3), 211-221. https:/ / doi.org/10.1093/elt/XXXI.3.211

Suraprajit, P. (2017). Communication strategies used by Thai service providers in Pattaya City, Thailand. International Journal of Arts and Sciences, 9(4), 71-82.

Swender, E. (1999). ACTFL Oral Proficiency Interview Tester Training Manual. Yonkers, NY: American Council on the Teaching of Foreign Languages.

Tarone, E. (1977). Conscious communication strategies in interlanguage: A progress report. In Z. Dörnyei \& M. L. Scott. (1997) Communication strategies in a second language: Definitions and taxonomies. Language Learning, 47, 173-210.

Ting, S. H., \& Kho, T. P. (2009). Gender and communication strategy use in learning English as a second language. International Journal of Applied Linguistics, 157(1), 93-108. https://doi.org/10.2143/ITL.157.0.2042589

Ting, S. H., \& Phan, G. Y. L. (2008). Adjusting communication strategies to language proficiency. Prospect: An Australian Journal on TESOL, 23(1), 2836.

Tsai, C. C. (2018). The effects of communication strategy training on EFL speaking anxiety and speaking strategy among the community college adult learners in Taiwan. International Forum of Teaching and Studies, 14(2), 3-19.

Ventola, E. (1992). Writing scientific English: Overcoming intercultural problems. International Journal of Applied Linguistics, 2(2), 191-220. DOI:10.1111/j.1473-4192.1992.tb00033.x

Zhu, X., Liao, X., \& Cheong, C. M. (2019). Strategy use in oral communication

Journal of English Language Teaching Innovations and Materials (JELTIM), 2(2), 63-84

Copyright ( 2020 by JELTIM, e-ISSN 2657-1617 
with competent synthesis and complex interaction. Journal of Psycholinguistic Research, 48, 1163-1183. https://doi.org/10.1007/s10936019-09651-0

\section{Authors' Brief CV}

Megawati Soekarno graduated with a $\mathrm{PhD}$ (Applied Linguistics) from Universiti Malaysia Sarawak in 2019, and is currently a lecturer in Universiti Malaysia Sabah. Her research interests lie in communication strategy training and English for Occupational Purposes.

Su-Hie Ting has a PhD (Applied Linguistics) from the University of Queensland, a Masters of Science (Teaching of English as a Second Language) from Universiti Putra Malaysia and a Bachelor of Arts (Hons) from Universiti Sains Malaysia. She teaches research methodology at the Faculty of Language and Communication, Universiti Malaysia Sarawak. She has published on communication strategies, language choice and identity, academic writing, and health risk communication. 